\title{
Pengaruh Manajemen Tenaga Pendidik Terhadap Prestasi Belajar Peserta Didik di SD Harapan Indonesia Kota Bekasi
}

\author{
Netti Natarida Marpaung \\ Sekolah Tinggi Ilmu Ekonomi Tribuana \\ natarida.nm@gmail.com
}

\begin{abstract}
Abstrac
This research aims to determine and analyze the influence of teaching staff management on learning achievement. The research in this paper uses a quantitative method with an associative approach. The variables related in this study are teaching staff management $(X)$, and learning achievement $(Y)$. The data sources used consist of primary data, namely data obtained directly from research respondents through questionnaires, the samples in this research parents and teachers who were taken randomly totaling 80 people. The test was carried out using SPSS 25. The results obtained from this research indicate that teacher management has a positive and significant effect on student learning achievement at Harapan Indonesia Elementary School in Bekasi City. Based on the results of the partial test ( $t$ test) it can be concluded that the teacher management variable has a significant effect on student learning achievement because the value of tcount (25.659) > $t$ table (0.1984) with a significance of 0.000 t table (0.1984) with a significance of 0.066

Keywords: Teacher management, student learning outcomes
\end{abstract}

\begin{abstract}
Abstrak
Penelitian ini bertujuan untuk mengetahui dan menganalisis pengaruh manajemen staf pengajar terhadap prestasi belajar. Penelitian dalam tulisan ini menggunakan metode kuantitatif dengan pendekatan asosiatif. Variabel yang terkait dalam penelitian ini adalah manajemen staf pengajar (X1), dan prestasi belajar (Y). Sumber data yang digunakan terdiri dari data primer yaitu data yang diperoleh langsung dari responden penelitian melalui kuesioner, sampel dalam penelitian ini adalah orangtua murid dan guru yang diambil secara acak berjumlah 80 orang. Pengujian dilakukan dengan menggunakan SPSS 25. Hasil yang diperoleh dari penelitian ini menunjukkan bahwa manajemen guru berpengaruh positif dan signifikan terhadap prestasi belajar murid di SD Harapan Indonesia di Kota Bekasi. Berdasarkan hasil uji parsial (uji t) dapat disimpulkan bahwa variabel manajemen guru berpengaruh signifikan terhadap prestasi belajar murid karena nilai thitung $(25,659)>t$ tabel $(0,1984)$ dengan signifikansi sebesar 0,000 t tabel $(0,1984)$ dengan signifikansi 0,066

Kata Kunci : Manajemen Guru, Hasil belajar siswa
\end{abstract}

\section{PENDAHULUAN}

Sekolah sebagai sistem memiliki komponen yang saling terkait dan saling mempengaruhi dalam mencapai tujuan organisasi. Input sekolah meliputi: siswa, tenaga pendidik, keuangan, serta instrumental dan environmental, input lainnya harus dapat didayagunakan seefektif mungkin dalam proses transformasi, untuk menghasilkan output berupa peserta didik yang memiliki seperangkat nilai, sikap, pengetahuan serta keterampilan baru. Mendayagunakan semua sumber daya tersebut, diperlukan pengelolaan sekolah yang baik. Penyelenggaraan sekolah sesuai dengan standar nasional pendidikan yang dirumuskan oleh 
pemerintah. Standarisasi yang dimaksud menurut Peraturan Pemerintah Nomor 19 tahun 2005 meliputi standar pendidik tenaga kependidikan, standar proses, standar isi, standar pembiayaan, standar sarana prasarana, standar pengelolaan, standar kompetensi lulusan, dan standar penilaian.

Hasil penelitian Hidayati (2014:65) menjelaskan sebagai berikut: kepemimpinan pendidikan yang baik sangat mempengaruhi mutu pendidikan. Peran kepemimpinan pendidikan sangat menunjang keberhasilan tenaga pendidik. Kepemimpinan memegang peranan penting dalam pengelolaan sekolah, seluruh komponen sekolah digerakkan oleh kepala sekolah dengan skill dan kemampuannya. Kepala sekolah berupaya untuk mempengaruhi seluruh warga sekolah untuk mencapai visi dan misi sekolah, sehingga tujuan sekolah yang telah direncanakan dapat tercapai.

Tenaga pendidik merupakan unsur yang sangat mempengaruhi tercapainya tujuan pendidikan selain unsur murid dan fasilitas lainnya. Keberhasilan penyelenggaraan pendidikan sangat ditentukan kesiapan tenaga pendidik dalam mempersiapkan peserta didiknya melalui kegiatan belajar mengajar. Namun demikian posisi strategis tenaga pendidik untuk meningkatkan mutu hasil pendidikan sangat dipengaruhi oleh kemampuan profesional tenaga pendidik dan mutu kinerjanya. Begitu juga dengan tenaga pendidikan yang segala administrasi sekolah, sehingga arsip-arsip dan database komponen sekolah dapat terkelola dan terpelihara dengan baik. Tenaga pendidik menjadi bagian yang terpenting bagi sekolah dalam mencapai visi dan misi sekolah. Kepala sekolah bertanggungjawab terhadap sukses atau tidaknya sekolah yang dipimpin, kepala sekolah merupakan faktor kunci, karena kepala sekolah memegang peranan penting dalam pengelolaan sekolah. Pembinaan terhadap tenaga pendidik merupakan salah satu tugas dari kepala sekolah sebagai pemimpin sekolah, namun dalam pembinaan terhadap tenaga pendidik masih sangat memperhatinkan, program dan kegiatan pembinaan serta pengembangan kompetensi tenaga pendidik, khususnya komponen-komponen profesional.

Memang tolak ukur kemajuan suatu sekolah tidak hanya dapat diukur dari input siswa yang tinggi, namun faktor kualitas tenaga pendidik yang memberikan pengajaran kepada siswa 
juga sangat menentukan. Setiap satu kelas didampingi oleh 2 orang tenaga pendidik, sehingga memberikan pelayanan pengajaran dan pendidikan kepada siswa sangat intensif. Pengelolaan tenaga pendidik sangatlah perlu diperhatikan dalam upaya peningkatan mutu sekolah.

\section{Tujuan Penelitian}

1. Untuk mengetahui pengaruh manajemen tenaga pendidik terhadap perstasi belajar peserta didik di Sekolah Dasar Harapan Indonesia Bekasi

2. Untuk mengetahui hubungan majemen tenaga pendidik terhadap prestasi belajar peserta didik di Sekolah Dasar Harapan Indonesia Bekasi

\section{Hipotesis}

Hipotesis merupakan dugaan, kesimpulan atau jawaban sementara terhadap permasalahan yang telah di rumuskan di dalam rumusan masalah sebelumnya. Atas dasar masalah dan tujuan pembahasan dalam penelitian ini, maka hipotesis yang dikemukakan adalah :

\section{Hipotesis 1}

H0: Diduga ada pengaruh antara manajemen tenaga pendidik terhadap prestasi belajar peserta didik di Sekolah Dasar Harapan

Indonesia Bekasi

Ha: Ada pengaruh antara manajemen tenaga pendidik terhadap prestasi belajar peserta didik di Sekolah Dasar Harapan Indonesia Bekasi

2. Hipotesis 2

H0 : Tidak ada hubungan antara variabel manajemen tenaga pendidik dengan prestasi belajar peserta didik.

$\mathrm{Ha}$ : Ada hubungan antara variabel manajemen tenaga pendidik dengan prestasi belajar peserta didik.

\section{METODOLOGI PENELITIAN}

\section{Obyek Penelitian}

Objek Penelitian adalah Sekolah

Dasar Harapan Indonesia Bekasi bertempat di Harapan Jaya Kota Bekasi.

\section{Waktu Penelitian}

Waktu penelitian ini dilaksanakan bulan Februari tahun 2020 sampai dengan bulan Juni tahun 2020 dengan menyebar kuisioner pada orang tua murid dan guru-guru yang ada di Sekolah Dasar Harapan Indonesia Bekasi.

Alat analisis yang di gunakan adalah :

\section{Uji Instrumen}


Instrumen yang digunakan dalam penelitian ini adalah kuesioner yang dapat memberikan data yang membentuk kesiapan pada tingkat individu. Kuesioner merupakan tekhnik pengumpulan data yang dilakukan dengan cara memberi seperangkat pertanyaan atau pernyataan tertulis kepada responden untuk dijawabnya.

\section{Uji Vadilitas}

Ghozali (2011, hal 53) mengemukakan uji validitas di gunakan untuk mengukur sah atau tidaknya suatu kuesioner. Suatu kuesioner dikatakan valid jika pertanyaan pada kuesioner mampu mengungkapkan sesuatu yang akan diukur oleh kuesioner tersebut (Marpaung, 2021b)(Marpaung, 2021a). Uji validitas dilakukan dengan membandingkan nilai $r$ hitung dengan nilai $\mathrm{r}$ table untuk degree of feedom $d(f)=n-2$ dengan alphan 0,05. Jika $r$ itung lebih besar dari $\mathrm{r}$ table dan $\mathrm{r}$ positif, maka butir atau pertanyaan tersebut di katakana valid. Untuk pengujian validitas imstrumen dalam penelitian ini menggunakan rumus korelasi sebagai berikut :

$r$ hitung $=\frac{N\left(\sum X Y\right)-\left(\sum X\right)\left(\sum Y\right)}{\left\{N \cdot \sum X^{2}-\left(\sum \llbracket X\right) \rrbracket^{2}\right\}\left\{N \cdot \sum^{2}-\sum Y\right)^{2}}$

\section{Keterangan:}

$\mathrm{r}$ hitung $=$ koefisien korelasi

$\mathrm{N}$ = banyaknya butir pertanyaan
$\mathrm{X}=$ jumlah skor butir

$\mathrm{Y}=$ skor total responden

$X^{2}=$ jumlah kuadrat skor $X$

$Y^{2}=$ Dalam pengujian validitas instrument menggunakan rumus korelasi product momen untuk mengetahui antara skor butir (X) dengan skor tunggal (Y). Data di olah melalui program SPSS versi 17 , untuk membuktikan hasil analisis dapat di lihat pada output uji realibitas bagian corrected item total correlation.

\section{Uji Reabilitas}

Alat untuk mengukur suatu kuesioner yang mempunyai indikator dari variabel atau konstruk. (Ghozali 2011 hal 47) mengemukakan sebuah kuesioner dinyatakan reliable jika jawaban seseorang terhadap pernyataan adalah konsisten atau stabil dari waktu kewaktu.

Uji realibilitas ini dapat digunakan melalui program SPSS versi 25, yang akan memberikan fasilitas untuk mengukur nilai reliabilitas dengan menggunakan uji statistic cronbach alpa (a)

Suatu konstruck atau variabel dikatakan realiable jika memberikan nilai cronbach alpa $(a)>0,60$ (Ghozali 2011:48), untuk menguji realibilitas instrumen dilakukan dengan 
menggunakan rumus alpha cronbach dengan pormula sebagai berikut:

$$
r 11=\left(\frac{K}{K-1}\right)\left(1-\frac{\sum o^{2}}{o^{2}}\right)
$$

\section{Keterangan:}

r11 = Nilai reliabilitas

$\mathrm{k}=$ Jumlah item

$\sum o^{2}=$ Jumlah varians skor tiap-tiap item

$o^{2}=$ Varians total

\section{Uji Analisis}

Dalam uji analisi terdapat uji korelasi, regresi dan determinasi, berikut penjelasannya:

\section{Uji Korelasi}

Korelasi merupakan salah satu tekhnik analisi dalam statistik yang digunakan untuk mencari hubungan antara dua variabel yang bersifat kuantitatif. Hubungan dua variabel tersebut dapat terjadi karena adanya hubungan sebab akibat atau dapat juga terjadi karena kebetulan saja. Dua variabel dikatakan berkorelasi apabila perubahan pada variabel yang satu akan diikuti perubahan pada variabel yang lain secara tertentu dengan arah yang sama (korelasi positif) atau berlawanan (korelasi negative).

$r x y=\frac{N\left(\sum X Y\right)-\left(\sum X\right)\left(\sum Y\right)}{\left\{N \cdot \sum X^{2}-\left(\sum X\right)^{2}\right\}\left\{N \cdot \sum Y^{2}-\sum Y\right)^{2}}$

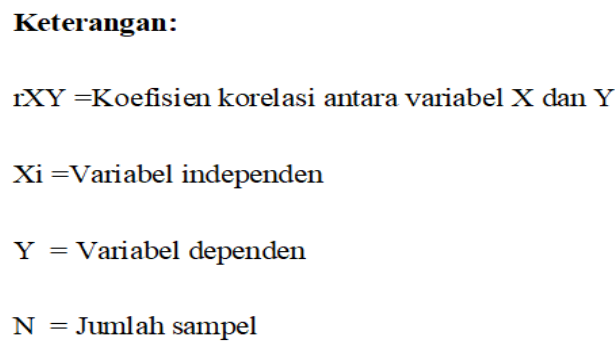

Analisis korelasi ini lebih lanjut diolah menggunakan bantuan program Statistical Product and Service Solution (SPSS versi 20). Langkah-langkahnya yaitu: (1) data yang digunakan sama dengan data untuk menghitung normallitas dan linieritas; (2) Analize > Correlate > Bivariate; (3) masukkan kedua variabel pengaruh manajemen tenaga pendidik dan prestasi belajar peserta didik ke dalam Variabel; (4) OK. Analisi korelasi digunakan untuk mengetahui keeratan antara dua variabel dan untuk mengetahui arah hubungan yang terjadi. Pada penelitian ini Korelasi Sederhana menggukan Product Moment Pearson dengan nilai korelasi (r) berkisar antara

a.1 sampai -1. Nilai semakin mendekati 1 atau -1 berarti hubungan antara dua variabel tersebut semakin kuat.

b. sebaliknya nilai mendekati 0 berarti hubungan antara dua variable semakin lemah.

c. Nilai positif menununjukkan hubungan searah (X naik, maka 
Y naik) dan nilai negatif menunjukkan hubungan terbalik (X naik, maka $\mathrm{Y}$ turun). Interpretasi koefisien korelasi menurut Sugiyono (2007) dalam Priyatno (2010) adalah sebagai berikut:

Tabel 3.10. Interpretasi Koefisien Korelasi

$0,00-0,199=$ sangat rendah

$0,20-0,399=$ rendah

$0,40-0,599=$ sedang

$0,60-0,799=$ kuat

$0,80-1,000=$ sangat kuat

\section{Uji Determinasi}

Bertujuan untuk mengukur seberapa jauh kemampuan perhitungan dalam menerangkan variasi variabel terikat (dependen). Nilai koefesien determinasi adalah di antara nol dan satu Pada pengujian hipotesis hipotesis pertama koefisien determinasi di lihat dari besarnya $\left(R^{2}\right)$ untuk mengetahui seberapa jauh variabel bebas yaitu penetapan harga serta pengaruhnya terhadap minat beli. Nilai $\left(R^{2}\right)$ mempunyai interval antara 0 dan 1 . Jika nilai $R^{2}$ bernilai besar (mendeteksi 1) berarti variabel bebas dapat memberikan hampir semua informasi yang di butuhkan untuk memprediksi variabel dependen.

Sedangkan jika nilai $\left(R^{2}\right)$ bernilai kecil berarti kemampuan variabel bebas dalam menjelaskan variabel dependen sangat terbatas. Secara umum koefisien determinasi untuk data silang (crosection) relative rendah karena adanya variasi yang besar antara masing pengamatan, sedangkan untuk data runtun waktu (time series) biasanya mempunyai nilai koefisien determinasi yang tinggi (Ghozali 2011).

Nilai koefisien determinasi yang kecil berarti kemampuan variabel independen dalam menjelaskan variasi variabel dependen itu terbatas. Nilai yang mendekati satu berarti variabel independen memberikan hampir semua informasi. Rumus yang digunakan untuk mencari koefisien determinan yang dikemukakan oleh Ridwan (2013:139) adalah sebagai berikut:

\section{$K D=r 2 \times 100 \%$}

$$
\begin{aligned}
& \text { Keterangan: } \\
& \mathrm{KD}=\text { Koefisien Determinan } \\
& \mathrm{r}=\text { Koefisien Korelasi }
\end{aligned}
$$

\section{Uji Regresi}

Regresi dipergunakan untuk mengolah hubungan antara dua variabel atau lebih terutama untuk menelusuri pola hubungan yang modelnya belum diketahui dengan sempurna atau untuk mengetahui bagaimana variabel independen berpengaruh terhadap uji 
digunakan menguji apakah variabel independen secara parsial mempunyai pengaruh yang signifikan terhadap variabel dependen. Variabel independen dikatakan secara parsial berpengaruh signifikan terhadap variabel dependen apabila signifikan $($ sig) $<$ a yaitu 0.05 adapun tanda positif (+) atau negative () dari beta dan $\mathrm{t}$ menunjukan arah variabel.

Apabila negative (-) maka variable tersebut berpengaruh negative artinya menurunkan tingkat volume penjualan dan apabila positif (+) maka variabel independen berpengaruh berarti meningkatkan volume penjualan.

\section{Uji Hipotesis}

Hipotesis merupakan asumsi atau dugaan mengenai suatu hal yang dibuat untuk menelaskan hal tersebut dan dituntut untuk melakukan pengecekannya. Jika asumsi atau dugaan tersebut dikhususkan mengenai populasi, umunya mengenai nilai-nilai parameter populasi, maka hipotesis itu disebut dengan hipotesis statistik.

HO : Tidak terdapat pengaruh manajemen tenaga pendidik terhadap prestasi belajar peserta didik di Sekolah Dasar Harapan Indonesia Bekasi .

H1 : Terdapat pengaruh manajemen tenaga pendidik terhadap prestasi belajar peserta didik di sekola $\mathrm{h}$ dasar islam terpadu

\section{Uji Statistik t}

di gunakan untuk menguji apakah variabel independen secara fersial mempunyai pengaruh yang signifikan terhadap variabel dependen signifikan $($ sig $)<$ a yaitu 0.05 . adapun tanda positif (+) atau negative (-) dari B eta dan t menunjukan arah variabel.

\section{HASIL DAN PEMBAHASAN}

\section{Analisis dan Penyajian Data Deskriptif}

Pada bab IV ini akan di uraikan dan di jelaskan mengenai data deskriptif dari penelitian yang telah di lakukan dengan judul pengaruh manajemen tenaga pendidik terhadap prestasi belajar peserta didik. Di dalam penelitian ini penulis menyebarkan kuisioner kepada para guru, kuesioner yang disebarkan terdiri dari dua bagian, yaitu tentang manajemen tenaga pendidik dan prestasi belajar peserta didik. Untuk mendapatkan gambaran mengenai karakteristik guru yang terpilih sebagai responden, berikut diuraikan pengelompokan responden berdasarkan jenis kelamin, usia, pendidikan dan pekerjaan responden. 


\section{Uji Validitas}

Gambar 4.3

Hasil uji validitas manajemen tenaga pendidik $(X)$

\begin{tabular}{|c|c|c|c|c|c|c|}
\hline & & Corre & tions & & & \\
\hline & & $\mathrm{X} 1$ & $\times 2$ & $\times 3$ & $\times 4$ & I \\
\hline $\mathrm{X} 1$ & Pearson Correlation & 1 & $.311^{\prime \prime}$ & .225 & .099 & \\
\hline & Sig (2-tailed) & & .009 & .061 & .416 & \\
\hline & $\mathrm{N}$ & 70 & 70 & 70 & 70 & \\
\hline X2 & Pearson Correlation & $.311^{* \prime}$ & 1 & $.492^{* \prime}$ & .198 & \\
\hline & Sig. (2-tailed) & .009 & & .000 & .100 & \\
\hline & $\mathrm{N}$ & 70 & 70 & 70 & 70 & \\
\hline X3 & Pearson Correlation & .225 & $.492^{\prime \prime}$ & 1 & $.328^{\circ}$ & \\
\hline & Sig. (2-tailed) & .061 & .000 & & .006 & \\
\hline & N & 70 & 70 & 70 & 70 & \\
\hline $\mathrm{X} 4$ & Pearson Correlation & .099 & .198 & $.328^{* *}$ & 1 & \\
\hline & Sig. (2-tailed) & .416 & .100 & .006 & & \\
\hline & N & 70 & 70 & 70 & 70 & \\
\hline Ttal_X & Pearson Correlation & $.444^{* t}$ & $.617^{*}$ & $.789^{* *}$ & $.739^{*}$ & \\
\hline & Sig. (2-tailed) & .000 & .000 & .000 & .000 & \\
\hline & $\mathrm{N}$ & 70 & 70 & 70 & 70 & \\
\hline
\end{tabular}

Berdasarkan pernyataan di atas dari tabel di atas variabel manajemen tenaga pendidik (X) dari 4 item pernyataan adalah valid hal ini dapat dilihat dari nilai korelasi Rhitung 0,444 untuk setiap item pernyataan lebih besar dari nilai Rtable sebesar 0.235 (taraf signifikansi $5 \%$ dari $\mathrm{n}=70$ ). Dengan demikian maka dari 4 item dalam instrument persyaratan validitas atau secara statistic dari data tersebut dapat digunakan untuk mengukur penelitian selanjutnya.
Gambar 4.4

Hasil uji validitas prestasi belajar $(\mathbf{Y})$

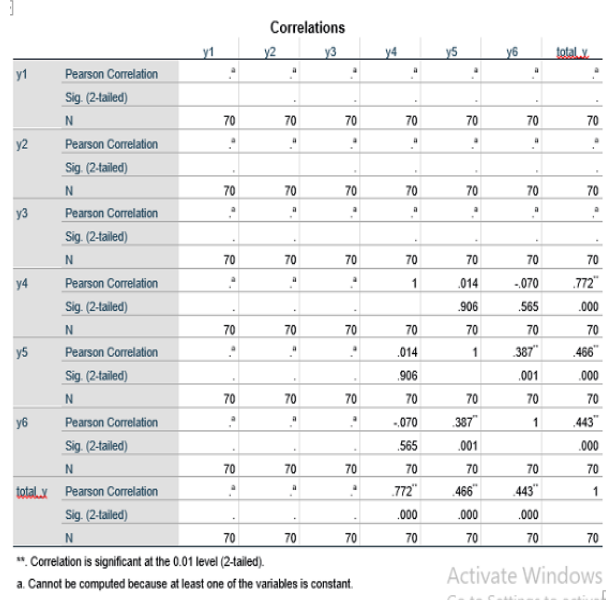

Berdasarkan pernyataan di atas dari tabel di atas variabel prestasi belajar (Y) dari 6 item pernyataan adalah valid hal ini dapat dilihat dari nilai korelasi Rhitung 0,772 untuk setiap item pernyataan lebih besar dari nilai Rtable sebesar 0.235 (taraf signifikansi $5 \%$ dari $\mathrm{n}=70$ ). Dengan demikian maka dari 6 item dalam instrument persyaratan validitas atau secara statistic dari data tersebut dapat digunakan untuk mengukur penelitian selanjutnya.

\section{Uji Reabilitas}

Untuk menguji reabilitas instrument di gunakan koefisien reliability Alpha Cronbach yang di perhitungannya menggunakan prosedur reliabilitas pada paket program software 
IBM SPSS statisticts versi. 25.0 for windows.

Menurut Sugiyono (2017:199) mengenai uji reliabilitas instrument adalah uji reliabilitas digunakan untuk mendapatkan hasil penelitian yang valid dan reliable dan digunakan untuk mengukur berkali-kali untuk menghasilkan data yang sama (konsistensi). Uji reabilitas dapat dikatakan reliable jika nilai combach alpha lebih besar dari 0,7 , sebaliknya jika nilainya kurang dari 0,7 maka tidak reliable. Hasil dari uji reliabilitas.

Tabel 4.5

\section{Hasil Uji Reabilitas}

\section{Variabel manajemen tenaga pendidik (X)}

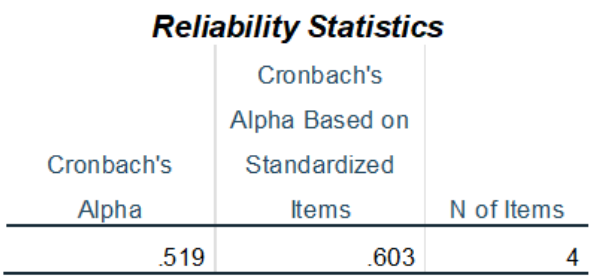

Sumber: data SPSS di olah tahun 2020

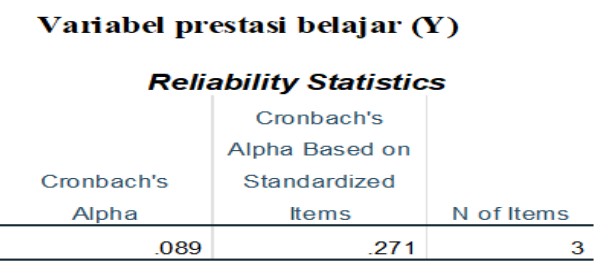

Berdasarkan tabel 4.4 di atas hasil SPSS variabel manajemen tenaga pendidik 0,519 variabel prestasi belajar 0,089 menunjukkan bahwa instrument setiap variabel penelitian adalah reliable atau konsisten karena jika nilai > 0,6. Maka reliable atau konsisten.

\section{Hasil Dan Pembahasan Uji Korelasi}

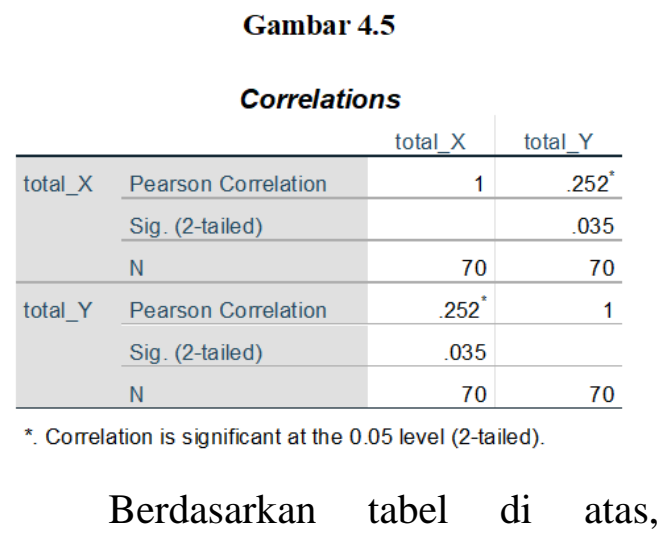

terlihat koefisien korelasi. 252". Artinya besar korelasi atau hubungan antara variabel manajemen tenaga pendidik terhadap prestasi belajar sebesar 0,252 atau rendah karena mendekati angka 1. Tanda dua bintang (**) artinya korelasi signifikan hingga pada angka signifikan sebesar 0,001. Berdasarkan tabel di atas hubungan variabel manajemen tenaga pendidik terhadap prestasi belajar signifikan karena angka signifikan $0,000<0,01$. Arah korelasi dapat dilihat dari angka koefisien hasilnya positif atau negative. Sesuai dengan hasil analisis,koefisien korelasi jauh bernilai positif yaitu 0,252 maka korelasi kedua variabel bersifat searah. 
Hasil Dan Pembahasan Uji

Determinasi

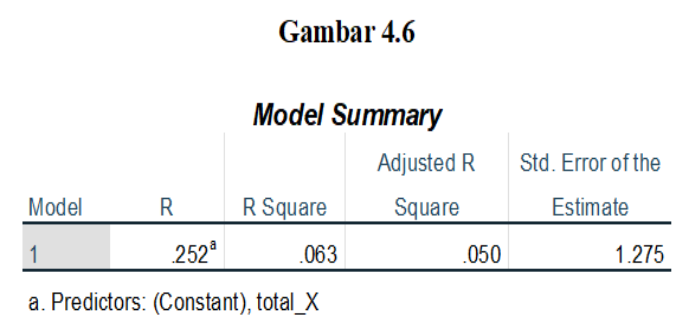

Dilihat dari hasil tabel di atas output SPSS di atas didapatkan nilai $\mathrm{R}$ (koefisien determinasi) 0,252 yang artinya pengaruh manajemen tenaga pendidik (variabel independen) adalah sebesar 0,63\% ini menunjukkan bahwa nilai $\mathrm{R}$ mencapai angka 1 dan variabel bebas dapat memberikan hampir semua informasi yang dibutuhkan untuk memprediksi variabel terikat (dependen)

\section{Hasil Dan Pembahasan Uji Regresi}

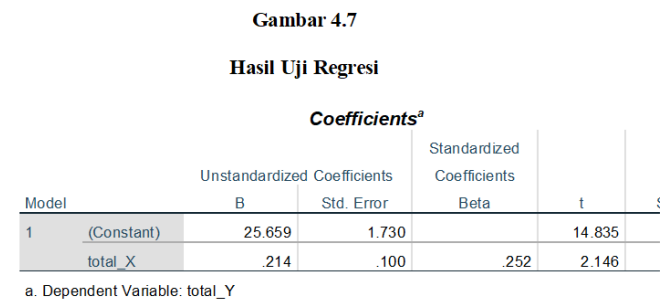

Dari data tabel 4.7 diatas perhitungan nilai regresi tersebut di pengaruhi nilai constant (a) sebesar 25.659 sedangkan nilai koefisien regresi sebesar 0,214 sehingga persamaan regresinya dapat di tulis sebagai berikut.

$$
\begin{aligned}
& Y=a+B x \\
& Y=-25.659+0,214 X
\end{aligned}
$$

Nilai konstanta sebesar 0,214 mengandung arti bahwa nilai konsisten variabel prestasi belajar adalah 0,214 Dan nilai koefisien regresi $\mathrm{X}$ sebesar 0,214 menyatakan bahwa setiap penambahan $1 \%$ nilai manajemen tenaga pendidik, maka nilai prestasi belajar bertambah sebesar 0,214.

\section{Hasil Dan Pembahasan Uji Hipotesis}

\section{Persial ( Uji T)}

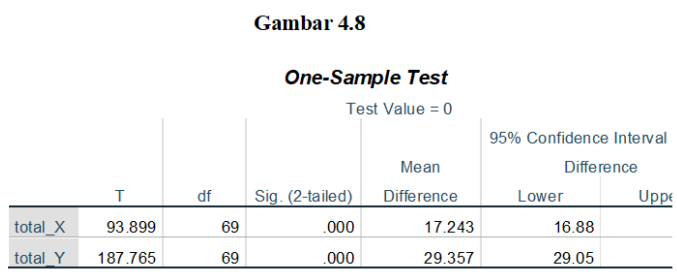

Berdasarkan table 4.8 di atas di ketahui nilai signifikan (sig) variabel manajemen tenaga pendidik 0,00. Karena nilai Sig 0,00. Probabilitas < 0,05, maka dapat di simpulkan bahwa penetapan harga di terima. Artinya ada pengaruh manajemen tenaga pendidik (X) terhadap prestasi belajar peserta $\operatorname{didik}(\mathrm{Y})$

\section{PENUTUP}

\section{Simpulan}

Berdasarkan analisis dan penelitian secara langsung dengan menyebarkan kuesioner, maka dapat diambil kesimpulan dan saran sebagai berikut: 
1. Dari hasil uji hipotesis melalui regresi linear sederhana Dengan SPSS versi 25 diperoleh ada korelasi (hubungan) yang signifikan antara variable manajemen tenaga pendidik terhadap prestasi belajar peserta didik di Sekolah Dasar Harapan Indonesia Bekasi. Dari hasil uji linearitas pengaruh manajemen tenaga pendidik terhadap prestasi belajar peserta didik terdapat nilai signifikan sebesar 0,000 lebih kecil dari 0,05 maka dapat dikatakan bahwa terdapat pengaruh antara variable bebas terhadap variable terikat secara parsial. Hasil uji $\mathrm{t}$ manajemen tenaga pendidik mempunyai tingkat signifikan sebesar 0,000 dan nilai t hitung sebesar 25.659 sedangkan nilai $\mathrm{t}$ table sebesar 0,19842 jadi t hitung lebih $>$ dari $t$ table maka $\mathrm{Ho}$ ditolak atau $\mathrm{Ha}$ diterima artinya manajemen tenaga pendidik berpengaruh terhadap prestasi belajar peserta didik.

2. Terdapat hubungan yang signifikan manajemen tenaga pendidik terhadap prestasi belajar peserta didik. Dibuktikan dengan nilai signifikan pada uji t secara parsial diperoleh nilai signifikasi sebesar 0,00 lebih kecil dari 0,05, sehingga dapat disimpulkan bahwa secara parsial hipotesis diterima dengan signifikan kuat.

\section{DAFTAR PUSTAKA}

Arikunto, Suharsimi. (2008). "Prosedur Penelitian". Jakarta : Rineka Cipta.

Ami Setiana Pratiwi. (2019). "Analisis Pengaruh Kualitas Pelayanan Terhadap Keuasan Konsumen Pada Restoran Siap Saji (KFC)”. Bekasi imur : STIE TIBUANA, Ekonomi Manajemen

Bilqies, Ana Fitriyatul. (2016). "Peran Kualitas Produk, Harga dan Kualitas Layanan terhadap Kepuasan pelanggan Billagio Skincare Sidoarjo". Jurnal Ekonomi Vol.1, No. 1, April 2016 : 78 - 90. Fakultas Ekonomi, Universitas Darul 'Ulum Lamongan.

Fardiani, Aprillia Nia. (2013). "Analisis Pengaruh Kualitas Pelayanan, Harga, Dan Promosi Terhadap Kepuasan Pelanggan Dyriana Bakery \& Café Pandanaran Semarang”. Penelitian. Semarang: UNDIP.

Melanesia, Herlinda. (2011). "Pengaruh Kualitas Pelayanan terhadap Kepuasan Nasabah Bank pada Nasabah PD BPR Bank Sleman di Kabupaten Sleman". Penelitian Tidak Diterbitkan. Yogyakarta: FE UNY. 
Marpaung, N. N. (2021a). Pengaruh

Kualitas Pelayanan Dan Harga

Terhadap Keputusan Pembelian

Air Minum Isi Ulang "Biru" Di Jl.

Jembatan 5 Pondok Timur - Kota

Bekasi. Parameter, 5(1), 12-25.

Https://Doi.Org/10.37751/Paramet er.V5i1.136

Marpaung, N. N. (2021b). Pengaruh Citra Merek Dan Kualitas Produk Terhadap Minat Beli Sepatu Ando (Studi Kasus Di Kota Bekasi 2020). Parameter, 5(2), 27-40.

Https://Doi.Org/10.37751/Paramet er.V5i2.147

Nurhadi. (2015). "Lensa Kegiatan Ekonomi”. Jakarta. Bailmu

Nurul Fajar. (2018). "Pengaruh Kualitas Pelayanan terhadap Kepuasan Pelanggan Pada Kedai Radja Ngopi”. Bekasi Timur: Sekolah Tinggi Stie Tribuana, Ekonomi Manajemen.

Panjaitan, Yuliati. (2016). "Pengaruh kualitas Pelayanan terhadap Kepuasan Pelanggan pada JNE cabang Bandung". Bandung. Fakultas Komunikasi dan Bisnis Universitas Telkom

Retna, Dewi Wulan. (2013). "Pengaruh Kualitas Produk dan Kualitas Pelayanan terhadap Kepuasan Pelanggan pada PDAM Tirta Pakuan Kota Bogor". Jurnal Online Mahasiswa Manajemen. Bogor: Sekolah Tinggi Ilmu Ekonomi Kesatuan.

Wahyuno, Cahyo. (2013). "Pengaruh Kualitas Pelayanan dan Harga terhadap Kepuasan Konsumen Pengguna Jasa Hotel Anugerah Glagah
Indah Temon Kulon Progo

Yogyakarta". Penelitian

Tidak

Diterbitkan.

Yogyakarta: FE UNY. 